\title{
PENGARUH PROFITABILITAS, LEVERAGE, DAN LIKUIDITAS TERHADAP TAX AVOIDANCE
}

\author{
Jamothon Gultom \\ Universitas Pamulang - Tangerang Selatan \\ E-mail: dosen01081@unpam.ac.id
}

\begin{abstract}
The existence of differences in interests between the government and taxpayers causes tax avoidance by taxpayers in the form of taking advantage of loopholes in the Taxation Law. This study aims to determine the Effect of Profitability, Leverage, and Liquidity on Tax Avoidance (Empirical Study on Property and Real Estate Companies listed on the Indonesia Stock Exchange in 2016-2019). From the results of the tests that have been carried out in this study, it can be concluded that profitability (Returnn on Assets) has a negative effect on tax avoidance, while Leverage (Debt to Equity Ratio) and Liquidity (Current Ratio) have no effect on tax avoidance in property and real estate companies 2016-2019
\end{abstract}

\section{Keywords: Profitability; Leverage; Liquidity; Tax Avoidance}

\begin{abstract}
Abstrak
Adanya perbedaan kepentingan antara pemerintah dengan wajib pajak menimbulkan tindakan penghindaran pajak oleh wajib pajak dalam bentuk memanfaatkan celah Undang-Undang Perpajakan. Penelitian ini ditujukan untuk mengetahui Pengaruh Profitabilitas, Leverage, dan Likuiditas terhadap Tax Avoidance (Studi Empiris pada Perusahaan Property dan Real Estate yang terdaftar di Bursa Efek Indonesia tahun 2016-2019). Dari hasil pengujian yang telah dilakukan dalam penelitian ini, dapat disimpulkan bahwa profitabilitas ( Returnn on Assets ) berpengaruh negatif terhadap tax avoidance sedangkan pada Leverage ( Debt to Equity Ratio ) dan Likuiditas (Current Ratio ) tidak berpengaruh terhadap tax avoidance di perusahaan property dan real estate tahun 2016-2019.
\end{abstract}

\section{Kata kunci: Profitabilitas; Leverage; Likuiditas; Tax Avoidance}

\section{PENDAHULUAN}

Pelaksanaan pemungutan pajak suatu negara memerlukan suatu sistem yang telah disetujui masyarakat melalui perwakilannya di dewan perwakilan, dengan menghasilkan suatu perundang-undangan yang menjadi dasar pelaksanaan sistem perpajakan bagi fiskus maupun bagi wajib pajak. Sistem pemungutan pajak yang berlaku di Indonesia berdasarkan peraturan perundang-undangan adalah Self 
Assesment System, di mana segala pemenuhan kewajiban perpajakan dilakukan sepenuhnya oleh wajib pajak, fiskus hanya melakukan pengawasan melalui prosedur pemeriksaan.

Menurut Waluyo (2011) salah satu cara untuk mewujudkan kemandirian bangsa dalam pembiayaan pembangunan adalah dengan menggali sumber dana dari pajak. Pemerintah terus berupaya memperbaiki sistem perpajakan menjadi lebih baik dalam rangka meningkatkan penerimaan negara dari pajak.

Di Indonesia, usaha-usaha untuk mengoptimalkan penerimaan sektor pajak bukan tanpa kendala. Seiring berjalannya perbaikan sistem perpajakan yang dilakukan oleh pemerintah, terdapat perbedaan kepentingan antara pemerintah dan perusahaan. Pajak di mata negara merupakan sumber penerimaan untuk membiayai penyelenggaraan pemerintahan, sedangkan pajak bagi perusahaan selaku wajib pajak adalah beban yang akan mengurangi laba bersih. Perusahaan berusaha untuk membayar pajak sekecil mungkin karena dengan membayar pajak berarti mengurangi kemampuan ekonomis perusahaan. Perbedaan kepentingan inilah yang menyebabkan wajib pajak cenderung untuk mengurangi jumlah pembayaran pajak, baik secara legal maupun ilegal. Usaha pengurangan pembayaran pajak secara legal disebut penghindaran pajak (tax avoidance), sedangkan usaha pengurangan pembayaran pajak secara ilegal disebut penggelapan pajak (tax evasion).

Penghindaran pajak (tax avoidance) merupakan persoalan yang rumit dan unik, di satu sisi penghindaran pajak diperbolehkan namun di sisi yang lain penghindaran pajak tidak diinginkan. Dalam konteks pemerintah Indonesia, telah dibuat berbagai aturan guna mencegah adanya penghindaran pajak. Salah satu aturan tersebut misalnya terkait transfer pricing, yakni tentang penerapan prinsip kewajaran dan kelaziman usaha dalam transaksi antara wajib pajak dengan pihak yang mempunyai hubungan istimewa (Perdirjen No. PER-32/PJ/2011).

Berdasarkan uraian dan fenomena di atas, tujuan dari penelitian ini adalah

1. Untuk mengetahui besarnya pengaruh profitabilitas terhadap tax avoidance pada perusahaan property dan real estate yang terdaftar di BEI tahun 2016-2018

2. Untuk mengetahui besarnya pengaruh leverage terhadap tax avoidance pada perusahaan property dan real estate yang terdaftar di BEI tahun 2016-2018.

3. Untuk mengetahui besarnya pengaruh likuiditas terhadap tax avoidance pada perusahaan property dan real estate yang terdaftar di BEI tahun 2016-2018.

Penulis berharap agar hasil dari penelitian ini dapat menambah pemahaman dalam memperkaya pengetahuan yang berhubungan tentang sejauh mana pengaruh profitabilitas, leverage, dan likuiditas terhadap tax avoidance pada perusahaan property dan real estate. Penelitian ini diharapkan juga dapat memberi masukan yang berharga dan dapat menjadi salah satu bahan evaluasi mengenai pengaruh profitabilitas, leverage, likuiditas terhadap tax avoidance.

\section{KERANGKA TEORITIS DAN PENGEMBANGAN HIPOTESIS}

Pada umumnya terdapat pemisahan antara pemilik perusahaan dengan manajemen yang akan mempengaruhi pertumbuhan dari bisnis suatu perusahaan.agar bisnis berjalan sesuai yang diharapkan maka para pemilik 
perusahaan atau pemegang saham akan memperkerjakan bisnis tersebut.adanya pemisahaan pemilik antara pemilik dengan manajemen yang menjalankan perusahaan ternyata menimbulkan konflik didalam perusahaan.konflik ini muncul karena kedua pihak akan berpikir untuk memenuhi kepentingan masigmasing.pemegang saham akan fokus pada peningkatan nilai sahamnya sedangkan manajer fokus pada pemenuhan kepentingan pribadi.

Menurut Handayani dan Putra (2013) terjadinya asimetri informasi pada perusahaan dapat memberikan informasi yang bukan sebenarnya sehingga informasi yang beredar tersebut dapat menyesatkan pengguna. Semakin banyak informasi yang diungkapkan berdasarkan standar maka menjadi sinyal positif bagi perusahaan sehingga akan berdampak dalam mengurangi asimetri informasi Adanya informasi tersebut dapat mendorong agen untuk membunyikan beberapa informasi yang tidak diketahui principal untuk memaksimalkan keuntungan bagi agen.

Rinaldi dan Cheisviyanny (2015) dalam penelitiannya mengemukakan terjadinya persinggungan antara kepentingan agen dan principal dalam hal mencapai kenerja terbaik perusahaan. Principal menginginkan agen untuk mengambil keputusan terbaik sehingga kinerja perusahaan maksimal namun agen cenderung mengambil keputusan yang menjadi risiko sehingga kinerjanya akan dinilai baik oleh principal dan menghindari dirinya dari pergantian, (Rinaldi \& Cheisviyanny, 2015).

Dari beberapa definisi di atas dapat disimpulkan teori agensi akan memacu para agen untuk meningkatkan laba perusahaan.ketika laba yang diperoleh membesar,maka jumlah pajak penghasilan akan meningkat sesuai dengan peningkatan laba perusahaan sehingga kecenderungan untuk melakukan tax avoidance yang dilakukan oleh perusahaan akan meningkat. Menurut (Noor et al., 2010) tax avoidance adalah upaya efisiensi beban pajak yang harus dibayarkan dengan cara menghindari pengenanaan pajak lewat berbagai jenis transaksi yang bukan merupakan objek pajak.

Tax avoidance adalah usaha untuk mengurangi,menghindari serta meringankan beban pajak dengan berbagai cara dimungkinkan oleh perundangundsngan perpajakan,dengan memperhatikan ada atau tidaknya suatu akibatnya yang ditimbulkan.(Ernest R.Mortenson dalam Zain : 2008). Menurut Harry graham balter tax avoidance adalah serangkaian kegiatan yang dilakukan oleh wajib pajak untuk mengurangi atau bahkan menghapus semua utanng pajak yang ada dengan suatu cara tertentu yang tidak melanggar undang-undang perpajakan.

Dari beberapa pengertian tersebut di atas, maka dapat disimpulkan bahwa penghindaran pajak (tax avoidance) adalah hambatan-hambatan yang terjadi dalam pemungutan pajak sehingga mengakibatkan beerkurangnya penerimaan kas negara. Perlawanan terhadap pajak terdiri dari perlawanan aktif dan perlawanan pasif. Tax avoidance didukung dengan perkembangan teknologi informasi dan semakin terbukanya perekonomian suatu negara akan memberi peluang bagi perusahaan untuk mengembangkan usahanya. Dalam penelitian Hoque at al. (2011), diungkapkan beberapa cara perusahaan melakukan penghindaran pajak. (1) menampakkan laba dari aktivitas operasional sebagai laba dari modal sehingga mengurangi laba bersih dan utang pajak perusahaan tersebut. (2) mengakui 
pembelanjaan modal sebagai pembelanjaan opersional, dan membebankan yang sama terhadap laba bersih sehingga mengurangi utang pajak perusahaan. (3) membebankan biaya personal sebagai biaya bisnis sehingga mengurangi laba bersih. (4) membebankan depresiasi produksi yang berlebihan di bawah nilai penutupan peralatan sehingga mengurangi laba kena pajak. (5) mencatat pembuangan yang berlebihan dari bahan baku dalam industri manufaktur sehingga mengurangi laba kena pajak, (Hoque, et al. 2011). Menurut Fadhilah (2014) dalam penelitiannya mengemukakan bahwa komite urusan fiskal dari Organization for Economic Cooperation and Development (OECD) telah menyebutkan tiga karakter penghindaran pajak (tax avoidance) yaitu:

a. Adanya unsur artifisial di mana berbagai pengaturan seolah olah terdapat di dalamnya padahal tidak, dan ini dilakukan karena ketiadaan faktor pajak.

b. Memanfaatkan loopholes dari Undang-Undang atau menerapkan ketentuan legal untuk berbagai tujuan, padahal bukan itu yang sebetulnya dimaksudkan oleh pembuat Undang-Undang.

c. Para konsultan menunjukkan alat atau cara untuk melakukan penghindaran pajak dengan syarat wajib pajak menjadi serahasia mungkin.

(Hanlon \& Heitzman, 2010) dalam penelitian menyatakan CETR merupakan ukuran ini seringkali digunakan sebagai proksi penghindaran pajak dalam berbagai riset pajak. CETR dihitung dengan menggunakan rasio beban pajak penghasilan kini terhadap pre-tax income. Cash ETR adalah effective tax rate berdasarkan jumlah kas pajak yang dibayarkan perusahan pada tahun berjalan. Cash Tax paid adalah jumlah kas pajak yang dibayarkan perusahaan i pada tahun $\mathrm{t}$ berdasarkan laporan keuangan perusahaan. Semakin kecil nila CETR berarti penghindaran pajak perusahaan semakin besar dan begitu sebaliknya semakin besar nila CETR berarti penghindaran pajak perusahaan semakin kecil. Nila CETR berkisar lebih dari 0 dan kurang dari 1. Kurniasih \& Ratna Sari, (2013) dalam penelitiannya menyatakan banyak cara yang bisa digunakan untuk mengukur adanya Tax avoidance. Kebanyakan proksi atau alat untuk pengukuran Tax Avoidance membutuhkan data dari laporan keuangan perusahaan dan akses untuk mendapatkan data tersebut. Sementara untuk pengukuran penghindaran pajak ini, peneliti akan menggunakan model Cash Effective Tax Rate (CETR) yang diharapkan mampu mengidentifikasi keagresifan perencanaan pajak perusahaan yang dilakukan menggunakan perbedaan tetap maupun temporer.

Profitabilitas adalah salah satu ukuran kinerja dalam menggambarkan kemampuan menghasilkan laba selama periode tertentu dalam suatu perusahaan (Darmawan \& Sukartha, 2014). Suatu perusahaan dengan profitabilitas yang baik, terlihat mempunyai nilai effective tax rates yang lebih tinggi. Profitabilitas diproksikan menggunakan proksi Returnn on Assets (ROA). ROA mampu mencerminkan kemampuan beroperasi perusahaan dalam mendapatkan laba. Perusahaan yang mampu mengelola pendapatan dan pembayaran pajaknya dianggap memperoleh laba sehingga diasumsikan tidak melakukan tax avoidance.

Profitabilitas adalah kemampuan perusahaan dalam menghasilkan keuntungan dengan semua modal yang bekerja di dalamnya, (Utami, 2017). Definisi lain profitabilitas adalah kemampuan perusahaan memperoleh laba dalam hubungannya dengan penjualan, total aktiva maupun modal sendiri. Agus Sartono 
(2010) dari beberapa pengertian di atas dapat disimpulkan profitabilitas adalah kemampuan perusahaan untuk mengukur tingkat hasil keuntungan atau laba di mana semua sumber daya bekerja di dalamnya.

Leverage adanya perbandingan antara besarnya utang yang digunakan untuk pembiayaan oleh perusahaan dalam menjalankan aktivitas operasinya (Praditasari \& Setiawan, 2017). Dalam hal ini rasio leverage digunakan untuk mengukur kemampuan perusahaan untuk membayar seluruh kewajiban, baik jangka panjang maupun pendek. DER merupakan rasio yang digunakan untuk menilai utang dan ekuitas (Kasmir, 2014). Rasio Leverage juga menunjukan risiko yang dihadapi perusahaan Leverage adalah rasio yang digunakan untuk mengukur sejauh mana aktiva perusahaan dibiayai dengan hutang. Artinya, berapa besar beban hutang yang ditanggung perusahaan dibandingkan dengan aktivanya. Dalam arti luas dikatakan bahwa rasio ini digunakan untuk mengukur kemampuan perusahaan untuk membayar seluruh kewajibannya baik jangka pendek maupun jangka panjang apabila perusahaan dilikuidasi.

Menurut Kasmir (2014) Leverage merupakan rasio yang menggambarkan antara hutang perusahaan terhadap modal maupun aset. Rasio ini dapat melihat seberapa jauh perusahaan yang digambarkan oleh modal (equity). Perusahaan yang baik mestinya memiliki komposisi modal yang lebih besar dari hutang. (Surbakti, 2012) dalam penelitian menyatakan Leverage merupakan tingkat hutang yang digunakan untuk perusahaan dalam melakukan pembiayaan. Leverage membiayai tingkat rasio dari perusahaan yang diukur dengan membandingkan total kewajiban perusahaan dengan total aktiva yang dimiliki perusahaan. Maka dari itu, semakin besar tingkat hutang yang dimiliki perusahaan semakin besar risiko yang akan ditanggung. Financial leverage merupakan proksi yang digunakan untuk menangkap keputusan pendaan perusahaan. Leverage adalah salah satu rasio keuangan yang menggambarkan hubungan antara hutang perusahaaan terhadap modal maupun aset perusahaan. Rasio leverage menggambarkan sumber dana operasi yang digunakan oleh perusahaan. Rasio leverage juga menunjukan risiko yang dihadapi perusahaan Menurut (Cahyono et al., 2016).

Masalah likuiditas berhubungan dengan masalah kemampuan perusahaan untuk memenuhi kewajiban finansialnya yang harus segera dipenuhi. Likuiditas perusahaan menunjukkan kemampuan untuk membayar kewajiban finansial jangka pendek tepat pada waktunya. Menurut Irham Fahmi (2015:65) definisi likuiditas adalah: "Kemampuan suatu perusahaan memenuhi kewajiban jangka pendeknya secara tepat waktu. Contoh: membayar listrik, telefon, air, gaji karyawan, gaji teknisi, gaji lembur, tagihan telepon dan sebagainya. Karena itu rasio likuiditas sering disebut dengan short term liquidity." Sedangkan definisi likuiditas menurut Mamduh M. Hanafi dan Halim (2014:37) adalah: "Kemampuan likuiditas jangka pendek perusahaan dengan melihat besarnya aktiva lancar relatif terhadap utang lancarnya." Menurut Kasmir (2014) rasio likuiditas adalah: "Rasio likuiditas atau sering disebut dengan nama rasio modal kerja merupakan rasio yang digunakan untuk mengukur seberapa likuidnya suatu perusahaan. Caranya adalah dengan membandingkan komponen yang ada di neraca, yaitu total aktiva lancar dengan total passiva lancar (utang jangka pendek)". Sofyan Harahap (2011:301) Rasio Likuiditas menggambarkan kemampuan perusahaan untuk menyelesaikan 
kewajiban jangka pendeknya, rasio-rasio ini dapat dihubungan melalui sumber informasi tentang modal kerja yaitu pos-pos aktiva lancar dan hutang lancar. Berdasarkan definisi-definisi di atas, dapat disimpulkan bahwa likuiditas adalah kemampuan perusahaan memenuhi kewajiban jangka pendek secara tepat waktu dengan melihat aktiva lancar terhadap utang lancar.

Kerangka pemikiran penelitian ini menunjukan pengaruh variabel independen,yaitu profitabilitas, leverage, dan ukuran perusahaan terhadap variabel dependen,yaitu Tax avoidance.kerangka pemikiran ini adalah sebagai berikut:

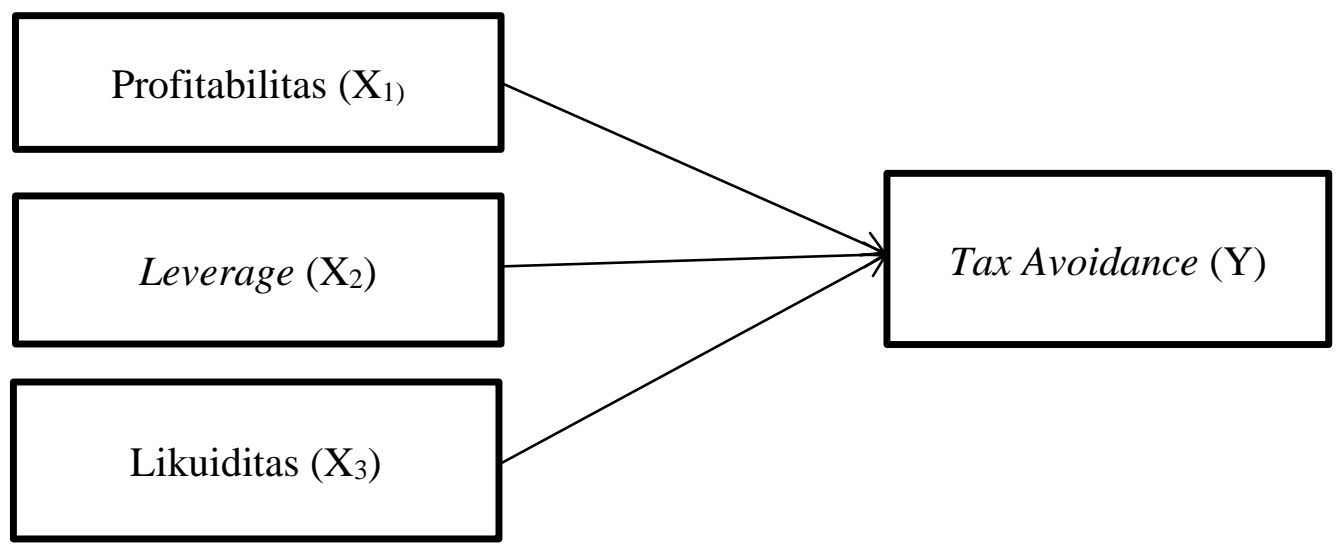

\section{Kerangka pemikiran}

\section{Hipotesis Penelitian}

Gambar 2.1

Profitabilitas adalah gambaran kemampuan perusahaan untuk menghasilkan laba. Profitabilitas terdiri dari beberapa rasio, salah satunya adalah return on asset pajak penghasilan. Return on asset (ROA) erat kaitannya pada laba bersih perusahaan termasuk juga pengenaan pajak penghasilan. Profitabilitas perusahaan terhadap penghindaran pajak akan memiliki hubungan positif. Jika nilai ROA tinggi, menjelaskan adanya efisien yang dilakukan oleh pihak manajemen. Laba yang meningkat mengakibatkan profitabilitas perusahaan juga meningkat, sehingga jumlah pajak yang harus dibayarkan tinggi hal ini meposisikan perusahaan dalam perencanaan pajak. Hasil penelitian Prakoso (2014) menunjukan bahwa profitabilitas berpengaruh secara signifikan.

H1 : Profitabilitas berpengaruh negatif terhadap penghindaran pajak (Tax avoidance)

Leverage merupakan rasio yang menunjukan besarnya komposisi utang suatu perusahaan. Leverage menggambarkan hubungan antara total aset dengan penggunaan utang untuk membiayai investasi (Kurniasih dan Ratnasari, 2013). Apabila operasional menggunakan hutang pada komposisi pembiayaan, maka akan timbul beban bunga yang harus dibayar sehingga menjadi pengurang penghasilan kena pajak. 
$\mathrm{H} 2$ : Leverage berpengaruh positif terhadap penghindaran pajak (Tax avoidance).

Irvan dan Henryanto (2015) mendefinisikan likuidias sebagai kemampuan perusahaan untuk memenuhi kewajiban jangka pendeknya yang secara konvensional, 'jangka pendek' dianggap periode hingga satu tahun meskipun dikaitkan dengan siklus operasional normal perusahaan. Dengan demikian likuiditas sangat penting bagi sebuah perusahaan. Likuiditas dapat digunakan untuk memperhitungkan dampak yang berasal dari ketidakmampuan perusahaan memenuhi kewajiban jangka pendeknya.

Hasil penelitian yang dilakukan oleh Suyanto dan Supramono (2012) menunjukkan bahwa likuditas perusahaan manufaktur memiliki pengaruh negatif namun tidak signifikan terhadap agresivitas pajak (tax avoidance).

H3 : Likuiditas berpengaruh positif terhadap penghindaran pajak (Tax avoidance).

\section{METODE RISET}

Penelitian ini menggunakan laporan keuangan pada perusahaan property pada tahun 2016-2019 yang diperoleh dari Bursa Efek Indonesia atau IDX untuk mendapatkan informasi laporan tahunan (annual report) dapat mengunjungi website resmi BEI yaitu www.idx.co.id Desain penelitian menggunakan metode penelitian kausal, penelitian yang bertujuan menganalisis hubungan sebab akibat antara variabel independen (variabel yang mempengaruhi) dan variabel dependen (variabel yang dipengaruhi).

Secara garis besar, terdapat dua jenis variabel yaitu variabel bebas (variabel independen) dan variabel terkait (dependen).

1. Variabel terikat (Dependent Variabel)

Variabel penelitian merupakan variabel yang menjadi perhatian utama pada penelitian. Variabel dependen adalah tipe variabel yang dijelaskan atau dipengaruhi oleh variabel independen Sugiyono (2016) .Dalam penelitiian ini, penulis mengambil penghindaran pajak sebagai variabel dependen. Penghindaran pajak (tax avoidance) merupakan upaya mengefesiensikan beban pajak dengan cara menghindari pengenaan pajak dengan mengarahkannya pada transaksi yang bukan objek pajak, Chairil (2015). Dalam penelitian ini tax avoidance diproksikan menggunakan rumus Cash effective rate (CETR) yaitu kas yang dikeluarkan untuk biaya pajak dibagi dengan laba sebelum pajak, pada Kurniasih, Tommy dan Ratnasari (2013), dengan rumus sebagai berikut:

$$
C E T R=\frac{\text { Pembayaran Pajak }}{\text { Laba Sebelum Pajak }}
$$

2. Variabel bebas (independen)

Variabel independen yang peneliti gunakan dalam penelitian ini ada tiga, yaitu profitabilitas, leverage, dan ukuran perusahaan. Ketiga variabel independen independen ini dijabarkan sebagai berikut: 


\section{Profitabilitas (ROA)}

Menurut Sofyan Harahap (2011), profitabilitas adalah rasio yang menggambarkan kemampuan perusahaan mendapatkan laba melalui semua kemampuannya,dan sumber yang ada seperti kegiatan penjualan,kas,modal,jumlah karyawan,jumlah cabang,dan sebagainya. Variabel ini diproksikan dengan menggunakan returnn on asset (ROA) yaitu perbandingan antara laba bersih dengan total asset pada akhir periode, yang digunakan indicator kemampuan perusahaan dalam menghasilkan laba. Kurniasih, Tommy dan Ratnasari (2013).

$$
R O A=\frac{\text { Laba Setelah Pajak }}{\text { Total Asset }} \times 100 \%
$$

\section{Leverage}

Leverage adalah rasio yang mengukur kemampuan utang baik jang panjang maupun jangka pendekmembiayai aktiva perusahaan (Kurniasih dan Ratnasari, 2013). Variabel ini diproksikan dengan menggunakan debt to equity ratio (DER) yaitu dengan menjumlahkan utang jangka panjang dan utang jangka pendek kemudian dibagi dengan jumlah modal, yang dirumuskan sebagai berikut:

$$
\text { Debt to Equity Ratio }=\frac{\text { Jumlah Utang }(\text { Debt })}{\text { Modal }(\text { Equity })} \times 100 \%
$$

\section{Likuiditas}

Menurut Kasmir (2013:130) rasio likuiditas adalah: "Rasio likuiditas atau sering disebut dengan nama rasio modal kerja merupakan rasio yang digunakan untuk mengukur seberapa likuidnya suatu perusahaan. Caranya adalah dengan membandingkan komponen yang ada di neraca, yaitu total aktiva lancar dengan total passiva lancar (utang jangka pendek)." Adapun indikator yang penulis gunakan untuk mengukur variabel ini adalah Current Ratio menurut Kasmir (2015:134), yaitu:

$$
\text { Current ratio }=\frac{\text { Current Asset }}{\text { Current Liabilities }} \times 100 \%
$$

Populasi yang digunakan adalah perusahaan property yang terdaftar di Bursa Efek Indonesi (BEI) dari tahun 2016-2019).

Metode pengambilan sampel dalam penelitian ini menggunakan metode purposive sampling di mana penentuan sampel didasarkan pada kriteria-kriteria sebagai berikut:

1. Terdaftar sebagai perusahaan property dan Real estate di BEI.

2. Perusahaan property dan real estate yang konsisten listing di BEI yaitu pada periode tahun 2016 - 2019. 
3. Perusahaan property dan real estate yang mempublikasikan laporan keuangan secara berturut-turut selama 4 (empat) tahun yaitu periode 2016 2019.

\section{ANALISIS DATA DAN PEMBAHASAN}

Populasi penelitian ini sebanyak 16 perusahaan perusahaan sektor property real estate yang terdaftar di BEI tahun 2016-2019, namun yang lolos kriteria sampel sebanyak 18 perusahaan sehingga total pengamatan menjadi 72 .

\section{Hasil uji satitistik deskriptif}

Tabel 1 Hasil Uji Statistik Deskriptif

Descriptive Statistics

\begin{tabular}{lcrrrr}
\hline & $\mathrm{N}$ & Minimum & Maximum & \multicolumn{1}{c}{ Mean } & Std. Deviation \\
\hline PROFITABILITAS & 72 & .004 & .220 & .05196 & .036210 \\
LEVERAGE & 72 & 123.000 & $4,343.000$ & $1,288.41667$ & 977.743316 \\
LIKUIDITAS & 72 & 652.00 & $11,399.00$ & $2,484.7778$ & $1,862.23271$ \\
TAX_AVOIDANCE & 72 & 2.000 & 575.000 & 152.77778 & 158.042892 \\
Valid N (listwise) & 72 & & & & \\
\hline
\end{tabular}

1. Variabel profitabilitas (ROA) bernilai terendah 0,004 data yang dimiliki PT Agung Podomoro Land Tbk, pada tahun 2019, Sementara nilai tertinggi sebesar 0,220 dimiliki oleh PT Lippo Cikarang, Tbk, ada tahun 2019.

2. Variabel leverage (DER) bernilai terendah 0,123 merupakan data yang dimiliki PT Lippo Cikarang Tbk, pada tahun 2019. Sementara nilai tertinggi sebesar 4,343 yang merupakan data PT Adhi Karya (Persero) Tbk, pada tahun 2019.

3. Variabel likuiditas bernilai terendah 0,652 merupakan data yang dimiliki PT Alam Sutera Realty Tbk, pada tahun 2018. Sementara nilai tertinggi sebesar 11,399 merupakan data yang dimiliki PT Bekasi Fajar Industrial Estate Tbk, pada tahun 2019.

\section{Hasil Uji Normalitas}

Tabel 2 Hasil Uji Normalitas 


\begin{tabular}{llr}
\multicolumn{2}{c}{ One-Sample Kolmogorov-Smirnov Test } \\
\hline $\mathrm{N}$ & & $\begin{array}{c}\text { Unstandardized } \\
\text { Residual }\end{array}$ \\
Normal Parameters ${ }^{\mathrm{a}}$ & Mean & 72 \\
& Std. Deviation & .0000000 \\
Most Extreme Differences & Absolute & $1.37137627 \mathrm{E} 2$ \\
& Positive & .130 \\
& Negative & .130 \\
Kolmogorov-Smirnov Z & & -.061 \\
Asymp. Sig. (2-tailed) & & 1.105 \\
a. Test distribution is Normal. & .174 \\
\hline
\end{tabular}

Pada tabel 2 di atas, dapat dilihat nilai probabilitas (Asymp.sig.2- tailed) yang diperoleh dari uji Kolmogorov-Smirnov sebesar 1.105, karena nilai probabilitas pada uji Kolmogorov-Smirnov masih lebih besar dari tingkat kekeliruan 5\% (0.05), maka disimpulkan bahwa model regresi berdistribusi normal.

\section{Hasil Uji Multikolinieritas}

\begin{tabular}{llrr}
\multicolumn{4}{c}{ Tabel 3 Hasil Uji Multikolonieritas } \\
Coefficients $^{\mathbf{a}}$ \\
\hline \multirow{3}{*}{ Model } & & \multicolumn{2}{c}{ Collinearity Statistics } \\
Tolerance & VIF \\
\hline 1 & PROFITABILITAS & .735 & 1.360 \\
& LEVERAGE & .560 & 1.785 \\
& LIKUIDITAS & .720 & 1.389 \\
\hline
\end{tabular}

a. Dependent Variable: TAX_AVOIDANCE

Suatu model regresi dinyatakan bebas dari multikolinieritas jika mempunyai nilai Tolerance lebih dari 0,10 dan nilai VIF kurang dari 10. Dari tabel 4.3 terlihat bahwa semua variabel bebas memiliki nilai Tolerance lebih dari 0,10 dan nilai VIF kurang dari 10, sehingga dapat disimpulkan tidak terdapat gejala multikolinieritas di antara ketiga variabel independen.

\section{Hasil Uji Autokolerelasi}

Tabel 4 Hasil Uji Autokorelasi Model Summary ${ }^{\mathrm{b}}$

\begin{tabular}{cccccc}
\hline \multicolumn{7}{c}{ Model Summary } \\
Model & $\mathrm{R}$ & R Square & $\begin{array}{c}\text { Adjusted R } \\
\text { Square }\end{array}$ & $\begin{array}{c}\text { Std. Error of the } \\
\text { Estimate }\end{array}$ & Durbin-Watson \\
\hline 1 & $.377^{\mathrm{a}}$ & .142 & .117 & .175518 & 1.714 \\
\hline
\end{tabular}

Oleh karena itu pengambilan keputusan adalah $\mathrm{dw}<\mathrm{du}<4$-du atau 1,714< $1,7411<2,258$, yang menunjukkan bahwa tidak ada autokorelasi positif atau negatif, atau dapat disimpulkan tidak autokorelasi. 


\section{Hasil Uji Heteroskedastisitas}

\begin{tabular}{|c|c|c|c|c|c|c|}
\hline \multicolumn{7}{|c|}{$\begin{array}{c}\text { Tabel } 5 \text { Hasil Uji Glesjer } \\
\text { Coefficients }^{\mathrm{a}}\end{array}$} \\
\hline & & \multicolumn{2}{|c|}{ Unstandardized Coefficients } & $\begin{array}{l}\text { Standardized } \\
\text { Coefficients }\end{array}$ & \multirow[b]{2}{*}{$\mathrm{t}$} & \multirow[b]{2}{*}{ Sig. } \\
\hline Model & & B & Std. Error & Beta & & \\
\hline \multirow[t]{4}{*}{1} & (Constant) & 124.030 & 32.766 & & 3.785 & .000 \\
\hline & PROFITABILITAS & -387.152 & 270.939 & -.190 & -1.429 & .158 \\
\hline & LEVERAGE & .013 & .011 & .172 & 1.132 & .262 \\
\hline & LIKUIDITAS & -.002 & .005 & -.060 & -.450 & .654 \\
\hline
\end{tabular}

a. Dependent Variable: ABRESID

Hasil Uji Heteroskedastisitas.

Tabel 6 Hasil Uji Koefisien Determinasi

\begin{tabular}{cccccc}
\multicolumn{8}{c}{ Model Summary $^{\mathrm{b}}$} \\
\hline Model & $\mathrm{R}$ & R Square & $\begin{array}{c}\text { Adjusted R } \\
\text { Square }\end{array}$ & $\begin{array}{c}\text { Std. Error of the } \\
\text { Estimate }\end{array}$ & Durbin-Watson \\
\hline 1 & $.377^{\mathrm{a}}$ & .142 & .117 & .175518 & 1.714 \\
\hline
\end{tabular}

Pada tabel 6 di atas, Adjusted $R$ Square sebesar 0,117 atau 11,7\%. Nilai tersebut menunjukkan bahwa profitabilitas, leverage, dan likuiditas memberikan kontribusi atau pengaruh terhadap tax avoidance sebesar $11,7 \%$. Sedangkan sisanya sebesar merupakan pengaruh dari faktor lain yang tidak diteliti.

\section{Hasil uji F}

\begin{tabular}{|c|c|c|c|c|c|c|}
\hline \multicolumn{7}{|c|}{$\underset{\text { ANOVA }^{\mathrm{b}}}{\text { Tabel }} 7 \underset{\text { Hasil Uji F }}{\text { F }}$} \\
\hline Model & & Sum of Squares & $\mathrm{Df}$ & Mean Square & $\mathrm{F}$ & Sig. \\
\hline \multirow[t]{3}{*}{1} & Regression & 438128.706 & 3 & 146042.902 & 7.437 & $.000^{\mathrm{a}}$ \\
\hline & Residual & 1335277.739 & 68 & 19636.437 & & \\
\hline & Total & 1773406.444 & 71 & & & \\
\hline
\end{tabular}

Nilai signifikan uji $\mathrm{F}<0.05$, dengan demikian dapat disimpulkan bahwa profitabilitas, leverage, dan likuiditas secara simultan berpengaruh terhadap tax avoidance pada perusahaan property and real estate yang terdaftar di Bursa Efek Indonesia.

\section{Hasil Uji t}

Tabel 8 Hasil Uji t 
Coefficients $^{\mathbf{a}}$

\begin{tabular}{|c|c|c|c|c|c|c|}
\hline \multirow{2}{*}{\multicolumn{2}{|c|}{ Model }} & \multicolumn{2}{|c|}{$\begin{array}{l}\text { Unstandardized } \\
\text { Coefficients }\end{array}$} & \multirow{2}{*}{$\begin{array}{c}\text { Standardized } \\
\text { Coefficients } \\
\text { Beta } \\
\end{array}$} & \multirow[b]{2}{*}{$\mathrm{t}$} & \multirow[b]{2}{*}{ Sig. } \\
\hline & & $\mathrm{B}$ & Std. Error & & & \\
\hline \multirow[t]{4}{*}{1} & (Constant) & 237.839 & 64.781 & & 3.671 & 0.000 \\
\hline & PROFITABILITAS & -1.383 & 0.536 & -0.317 & -2.582 & 0.012 \\
\hline & LEVERAGE & 0.021 & 0.023 & 0.128 & 0.911 & 0.365 \\
\hline & LIKUIDITAS & -0.016 & 0.011 & -0.189 & -1.525 & 0.132 \\
\hline
\end{tabular}

a. Dependent Variable: TAX_AVOIDANCE

Berdasarkan pengujian hipotesis pada tabel 8 maka dapat disimpulkan sebagai berikut:

1. Variabel profitabilitas memiliki nilai signifikan 0.012. Signifikan ini $<0,005$ yang menunjukkan bahwa variabel profitabilitas berpengaruh signifikan terhadap Tax avoidance.

2. Variabel Leverage memiliki nilai pada 0.365. Signifikan ini > 0,005 yang menunjukkan bahwa variabel leverage tidak berpengaruh signifiakan terhadap Tax avoidance.

3. Variabel likuiditas memiliki nilai signifikan pada 0.132. Signifikan ini >0,005 yang menunjukkan bahwa variabel likuiditas tidak berpengaruh signifikan terhadap Tax avoidance

Sehingga persamaan analisis regresi linier berganda dalam penelitian ini yakni:

$$
\mathrm{Y}=237.839-1.383 R O A+0.021 D E R-0.016 C R+\dot{\varepsilon}
$$

1. Nilai konstanta 237,839 artinya jika variabel profitabilitas, leverage dan likuiditas nilainya 0 , maka variabel tax avoidance nilai 237,839 .

2. Nilai koefisien regresi variabel profitabilitas sebesar - 1,383 dan bertanda negatif artinya jika profitabilitas mengalami kenaikan 1 point maka tax avoidance akan mengalami penurunan sebesar 1,383 dengan asumsi bahwa variabel independen lainnya tetap

3. Nilai koefissien regresi variabel leverage sebesar 0,021 dan bertanda positif artinya jika leverage mengalami kenaikan 1 point maka tax avoidance akan mengalami kenaikan sebesar 0,021 dengan asumsi bahwa variabel independent lainnya tetap.

4. Nilai koefisien regrei variabel likuiditas sebesar - 0,016 dan bertanda negatif artinya jika likuiditas mengalami kenaikan 1 point maka tax avoidance akan mengalalami penurunan sebesar 0,016 dengan asumsi variabel lainnya tetap.

\section{KESIMPULAN DAN SARAN}




\section{Kesimpulan}

Penelitian ini ditujukan untuk mengetahui Pengaruh Profitabilitas, Leverage, dan Likuiditas terhadap Tax Avoidance (Studi Empiris pada Perusahaan Property dan Real Estate yang terdaftar di Bursa Efek Indonesia tahun 2016-2019). Dari hasil pengujian yang telah dilakukan dalam penelitian ini, dapat disimpulkan bahwa:

1. Profitabilitas, Returnn on Assets berpengaruh negatif sebesar -1.383 pada tingkat signifikan 1 point terhadap tax avoidance di perusahaan property dan real estate tahun 2016-2019.

2. Leverage, Debt to Equity Ratio tidak berpengaruh terhadap tax avoidance di perusahaan property dan real estate tahun 2016-2019.

3. Likuiditas, Current Ratio tidak berpengaruh terhadap tax avoidance di perusahaan property dan real estate tahun 2016-2019

\section{Saran}

Saran yang dapat diberikan adalah untuk penelitian selanjutnya menggunakan sampel perusahaan lain dan menambah variabel penelitian lain. Untuk perusahaan yang di teliti sarannya adalah memperbaiki Kesehatan perusahaan dan melakukan perbaikan dalam mengelola keuangan perusahaan .

\section{DAFTAR PUSTAKA}

Agus Sartono. (2010). Manajemen Keuangan Teori dan Aplikasi. Edisi 4. Yogjakarta: BPFE

Cahyono, D. D., Rita, A., \& Kharis, R. (2016). Pengaruh Komite Audit, Kepemilikan Institusional, Dewan Komisaris, Ukuran Perusahaan (Size), Leverage (DER) dan Profitabilitas (ROA) terhadap Tindakan Penghindaran Pajak (Tax Avoidance) pada Perusahaan Perbankan yang Listing BEI Periode Tahun 2011-2013. Jurnal Akuntansi. Vol2. (No. 2)

Chairil Anwar, Pohan. (2015). Manajemen Perpajakan, Edisi 3. Jakarta: Gramedia Pustaka Utama

Cheisviyanny, Charoline \& Rinaldi. (2015). Pengaruh Profitabilitas, Ukuran Perusahaan dan Kompensasi Rugi Fiskal Terhadap Tax Avoidance Avoidance (Studi Empiris Perusahaan Manufaktur yang Terdaftar di BEI Periode 20112013). Jurnal Akuntansi Universitas Negeri Padang.

Darmawan, I. G. H., \& Sukartha, I. M. (2014). Pengaruh Penerapan Corporate Governance, Leverage, Return On Assets, dan Ukuran Perusahaan pada Penghindaran Pajak. E-Jurnal Akuntansi Universitas Udayana 9.1.

Fadhilah, Rahmi. (2014). Pengaruh Good Corporate Governance terhadap Tax Avoidance. Vol 2, No 1 . Jurnal Akuntansi Universitas Negeri Padang.

Fahmi, Irham. (2015). Pengantar Manajemen Keuangan Teori dan Soal Jawab. Bandung: Alfabeta. 
Hanafi, Mamduh M. dan Abdul Halim. (2014). Analisis Laporan Keuangan., Edisi tujuh., UPP AMP YKPN, Yogyakarta

Handayani, S., dan Putra, A. (2103). Dampak Asimetri Informasi Dan Manajemen Laba Terhadap Relevansi Informasi Akuntansi Pada Berbagai Tingkat Pengungkapan Laporan Keuangan Perusahaan Manufaktur Di Indonesia, Simposium Nasional Akuntansi XVI Manado.

Hanlon, Michelle., \& Heitzman, Shane. (2010). A review of tax research. Journal of Accounting and Economics, 50 (40). 127 - 178.

Harahap, Sofyan Syafri. (2011). Analisis Kritis atas laporan Keuangan. Edisi Pertam Cetakan ke sepuluh. Jakarta : PT Bumi Aksara.

Hoque, M. J., Bhuiyan, M. Z. H., Ahmad, A. (2011). Tax Evasion and Avoidance Crimes - A Study on Some Corporate Firms of Bangladesh. Tax management

Kasmir. (2014). Analisis Laporan Keuangan, cetakan ke-7. Jakarta: PT Raja Grafindo Persada

Kurniasih, Tommy dan Maria M. Ratna Sari. (2013). Pengaruh Return On Assets, Leverage, Corporate Governance, Ukuran Perusahaan, dan Kompensasi Rugi Fiskal pada Tax Avoidance. Buletin Studi Ekonomi Vol 18, No.1, Halaman 5865

Noor, Md Rohaya et al. (2010). Corporate Tax Planning: A Study on Corporate Effective Tax Rates on Malaysian Listed Company. International Journal of Trade, Economics and Finance Vol. 1 No. 2.

Praditasari, A., \& Setiawan, P. E. (2017). Pengaruh good corporate governance, ukuran perusahaan, leverage dan profitabilitas pada tax avoidance. ejurnal akuntansi , 19 (2), 1229-1258.

Prakoso, K. B. (2014). Pengaruh Profitabilitas, Kepemilikan Keluarga dan Corporate Governance Terhadap Penghindaran Pajak Di Indonesia. SNA 17 Mataram, Lombok, Universitas Mataram, 1-27.

Sugiyono. (2016). Metode Penelitian Kuantitatif, Kualitatif dan R\&D. Bandung: PT Alfabet.

Surbakti, Theresa Adelina Victoria. (2012). Pengaruh Karakteristik Perusahaan dan Reformasi Perpajakan Terhadap Penghindaran Pajak di Perusahaan Industri Manufaktur Yang Terdaftar di Bursa Efek Indonesia Tahun 2008-2010

Suyanto, K.D., \& Supramono. (2012). Likuiditas, Leverage, Komisaris Independen dan Manajemen Laba terhadap Agresivitas Pajak Perusahaan. Jurnal Keuangan dan Perbankan, 2 (16), 167-177.

Tiaras, Irvan dan Wijaya Henryanto. (2015). Pengaruh Likuiditas, Leverage, Manajemen Laba, Komisaris Independen, dan Ukuran Perusahaan Terhadap Agresivitas Pajak. Jurnal Akuntansi. Vol. XIX, No. 3.

Waluyo. (2011). Perpajakan Indonesia. Buku 2. Edisi 10. Penerbit Salemba Empat. Jakarta. 
Jurnal Akuntansi Berkelanjutan Indonesia - Vol. 4, No. 2, Mei 2021 - Gultom

Widiya Dwi Utami. (2017). Pengaruh Profitabilitas Dan Nilai Pasar Terhadap Harga Saham Pada Perusahaan Sektor Pertambangan Yang Tercatat Di Bursa Efek Indonesia (Bei) Periode 2011-2015. Repository UPI

Zain, Mohammad. (2008). Manajemen Perpajakan edisi 3. Jakarta: Salemba Empat. 